\title{
Histone H2B Type 1-K
}

National Cancer Institute

\section{Source}

National Cancer Institute. Histone H2B Type 1-K. NCI Thesaurus. Code C162949.

Histone H2B type 1-K (126 aa, $14 \mathrm{kDa}$ ) is encoded by the human $\mathrm{H} 2 \mathrm{BC} 12$ gene. This protein plays a role in chromatin condensation and antimicrobial defenses. 